\title{
Expertise, Common Sense, and the Atkins Diet
}

\section{Citation}

Shapin, Steven. 2007. Expertise, common sense, and the Atkins diet. In Public Science in Liberal Democracy, ed. J. Porter and P. W. B. Phillips, 174-193. Toronto: University of Toronto Press.

\section{Permanent link}

http://nrs.harvard.edu/urn-3:HUL.InstRepos:3425897

\section{Terms of Use}

This article was downloaded from Harvard University's DASH repository, and is made available under the terms and conditions applicable to Other Posted Material, as set forth at http:// nrs.harvard.edu/urn-3:HUL.InstRepos:dash.current.terms-of-use\#LAA

\section{Share Your Story}

The Harvard community has made this article openly available.

Please share how this access benefits you. Submit a story.

Accessibility 
Edited by JENE M. PORTER and

PETER W.B. PHILLIPS

\section{Public Science in Liberal Democracy}

UNIVERSITY OF TORONTO PRESS

Toronto Buffalo London 
(C) University of Toronto Press Incorporated 2007 Toronto Buffalo London

Printed in Canada

\section{ISBN 978-0-8020-9359-2}

(

Printed on acid-free paper

\section{Library and Archives Canada Cataloguing in Publication}

Public science in liberal democracy : the challenge to science and democracy / edited by Jene M. Porter and Peter W.B. Phillips.

Essays presented at a conference held in Saskatoon, Sask., Oct. 14-16, 2004. ISBN 978-0-8020-9359-2

1. Democracy and science - Congresses. 2. Science and state-Congresses. 3. Research - Government policy - Congresses. I. Porter, J.M. (Jene M.), 1937- II. Phillips, Peter W.B.

Q175.4.P83 $2007 \quad 303.48^{\prime} 3 \quad$ C2007-903910-3

University of Toronto Press acknowledges the financial assistance to its publishing program of the Canada Council for the Arts and the Ontario Arts Council.

University of Toronto Press acknowledges the financial support for its publishing activities of the Government of Canada through the Book Publishing Industry Development Program (BPIDP).

\section{Contents}

Preface ix

Abbreviations $\mathrm{x}$

Introduction: The History, Philosophy, and Practice of Public Science 3

JENE PORTER AND PETER W.B. PHILLIPS

\section{Section One: The History of Public Science in Theory and Practice}

1 The Element Publicum 23 LARRY STEWART

2 Science, Democracy, and Philosophy: From Marginal Achievements to Impossible Opportunities 40

CARL MITCHAM

3 Public Geoscience at the Frontiers of Democracy 60 DEBORAH R. HUTCHINSON AND RICHARD S. WILLIAMS, JR

4 Public Science, Society, and the Greenhouse Gas Debate 84 PETER J. COOK

\section{Section Two: Solutions to the Problems: Philosophic}

5 The Role of Humanities Policy in Public Science 111 ROBERT FRODEMAN 


\section{Expertise, Common Sense, and the Atkins Diet}

STEVEN SHAPIN

Different kinds of scientific expertise bear different kinds of relation to common sense and to lay concerns. Particle physics, for example, is hard to understand, and much of it is counter-commonsensical. But, for the most part, that is not a problem for the laity, just because it is not an expert practice that they care much about. Experts may regret this state of affairs; they may recommend new initiatives in the public understanding of science,' but, for present purposes, it is more pertinent to understand why there is such a lack of concern. In such cases, the public let experts, so to speak, 'get on with it,' and, if arid when the subject gets enshrined in the curriculum and there is a school examination to be passed, then the kids will have to learn the stuff. And if and when there is a concrete technology that emerges from such work, then the public may give it some attention themselves or they may assume that their democratically elected representatives should have the matter in hand. There just are not the sort of intermediate structures that allow the public to engage with such expertise in any other ways.

However, there are other technical practices whose scientific content may be hard to understand, and whose intellectual content may even conflict with lay models, but about which the laity care quite a lot. Any technical practice which purports to have a bearing on the doings of everyday life may engage lay concerns in this way - expertise on how to have good sex, how to raise the kids, and.how to launch a start-up company are all in this position. In the 1890s, Leo Tolstoy (1937: 186) criticized modern science for not having an answer to the question 'What should we do?' and in 1918 Max Weber (1991) celebrated modern science for just the same reason: 'Science is meaningless because it gives no answer to our question, the only question important for us: "What shall we do and how shall we live?"' (143). ${ }^{1}$ But, in fact, quite a lot of current scientific practices are in the business of supplying answers to that kind of question.

I want to talk about one version of this sort of modern expertise, one that illustrates different strands of technical expertise, enormous lay interest in the general field, enthusiastic lay take-up of some kinds of expertise, and vigorous lay rejection of other sorts. The case is dietetics and such cognate practices as nutrition science - anyway, expertise about what you ought to eat, and not eat, to avoid a range of diseases and to live a long and healthy life. Dietetics is now, and always has been, an expert practice that has the possibility of uniquely tight engagement with quotidian life, lay knowledge, and the texture of morality (Shapin 2003a). If you are lucky, you get to eat three times a day, seven days a week, so there are at least twenty-one occasions per week when the fork approaches the mouth. Each one of these is a possible occasion for the intercalation of expert knowledge between fork and mouth. In our sort of society, it is just not possible for food to be bought, prepared, and ingested unaccompanied by thoughts flowing from bodies of technical expertise: the relationship between dietary cholesterol and heart disease, fibre and colon cancer; the boundary between the amount of wine that is good for you and the amount that is not; and, of course, calorie content in relation to weight gain and loss. Every meal now comes polysaturated with technical expertise, and, while you can, at cost, decide to ignore it on this occasion, even ignoring expertise is a decision you probably have to take. In the main, however, the decision seems to be which type of expert commentary gets pride of place at this meal.

Dietetics is about exceedingly complex phenomena, and attempts to understand complex phenomena typically generate endemic expert disagreement. The British Astronomer-Royal Sir Martin Rees (2005) recently drew an instructive contrast between the security of scientific knowledge of simple things - the properties of celestial objects, for example - and the fragility of our knowledge of complicated things like human nutrition: 'Scientists still can't agree on what food is good for us. There is a real sense in which dietetics is harder than cosmology.' Questions about which expertise to invite to the table can be, and now often are, vexed decisions for the average eater. Almost needless to say, modern technical expertise about what you ought to eat is seriously divided. ${ }^{2}$ The heterogeneity of expertise on a very large number of occasions of public concern is a notable feature of our culture (as 
argued, for example, in Collins and Pinch 1998a and 1998b, Shapin 1992, and Barnes 1982). Walter Willett (2001a), a Harvard expert, freely admits that 'research about diet and nutrition seems to contradict itself with aggravating regularity' (27). Most laypeople probably know that expert dietetic claims are various and change rapidly, though it would be good to have more securely grounded understandings of what people do and do not know. Sometimes the diversity of conflicting expert voices encourages the laity to suspect that genuine expertise is not available in the area - as in psychiatric expert testimony on legal responsibility - but that is not a necessary inference for all areas of internally conflicted expertise. Dietetics seems to be a domain characterized by both very great expert heterogeneity and marked lay faith that authentic expertise must be available somewhere in the welter of conflicting claims. If one strand of dietetic expertise is treated with scepticism, then residual faith in the existence of expertise seems to be transferred to another claimant. The laity assert their freedom to pick and choose which expertise is credible, while giving few signs that they find the whole domain of dietary expertise wanting.

This is one further indicator of the way in which the body of expertise has become entrenched in our culture and what a long way we have come from the late sixteenth century, when Montaigne (1965: 827) thumbed his nose at the very idea of such expertise and its authority over his daily patterns of eating and drinking: 'The arts that promise to keep our body and our soul in health promise us much; but at the same time there are none that keep their promise less.' Expert physicians disagreed among themselves, and, so, if you did not like the dietary advice that one offered, you could always pitch one doctor's favoured rules against another's: . If your doctor does not think it good for you to sleep, to drink wine, or to eat such-and-such a food, don't worry: I'll find you another who will not agree with him' (833). For that reason alone, you might as well do what you thought best: you were, and ought to be, your own dietary physician (Shapin 2003a).

The USDA Food Pyramid (figure 9.1), initially published in 1992 with wide academic consultation, and much industry feedback, still seems to represent the condensation of academic expert knowledge among the nutrition scientists. Marion Nestle (2002: 66-8), one of the leading academic nutrition scientists, assures us that two-thirds of the American public know the original USDA Pyramid; that there is 'almost universal' expert consensus about its recommendations; and that genuine expert counsel has long been and will remain stable: it is a high-carbo-
Figure 9.1 USDA Food Guide Pyramid

The Food Guide

Pyramid

A Guide to Daily Food Choices

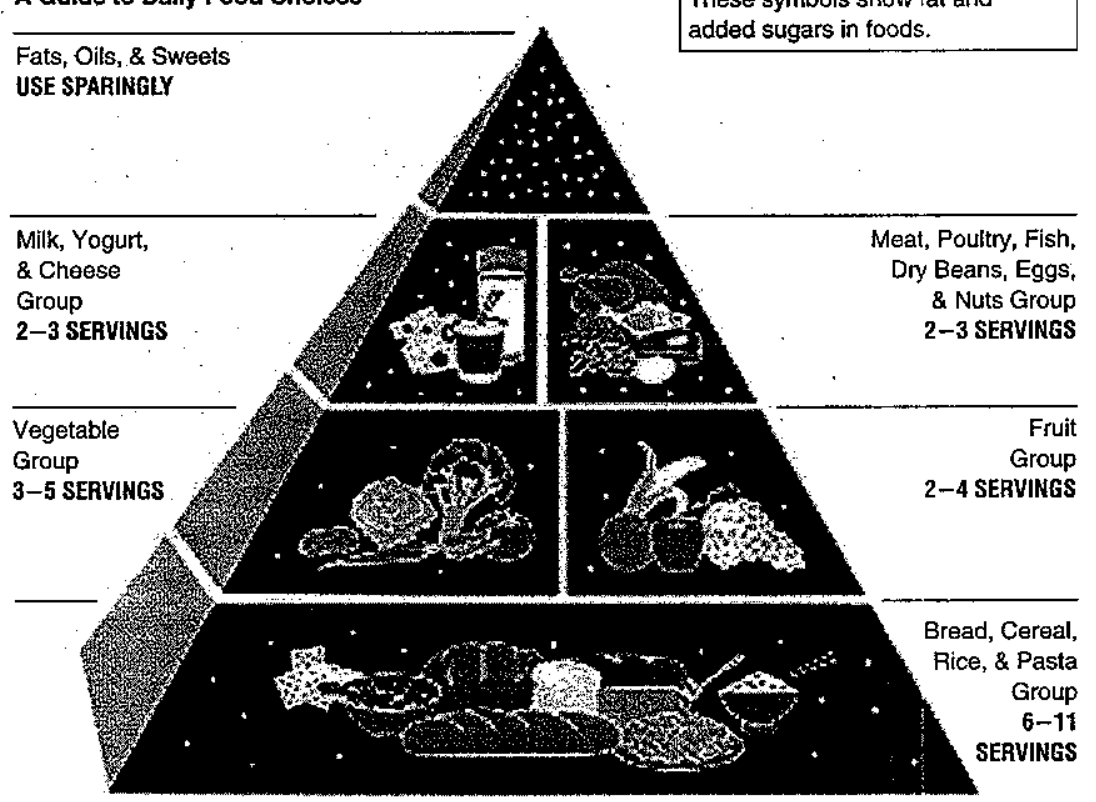

hydrate, high-fibre, low-protein, low-fat diet - pretty close to 'the Mediterranean diet' associated with the 1950s arid 1960s work of the pioneering nutrition scientist Ancel Keys (Keys and Keys 1959). ${ }^{3}$

However, when Nestle published her book Food Politics in 2002, the Pyramid was already considered ripe for revision. In February 2000, the USDA staged a public 'Great Nutrition Debate' among nutrition experts as a preliminary to revising the Pyramid and in September 2003 announced a program for that revision, partly as a response to anxieties that two-thirds of Americans were now classified as overweight or obese (Helmich 2002; Martin 2003). ${ }^{4}$ During the writing of the original draft of this paper, it was understood that the revised Pyramid was to be announced early in 2005, and the odds were that, while it would still be a relatively low-fat, low-protein diet, it would be substantially dif- 
Figure 9.2 MyPyramid

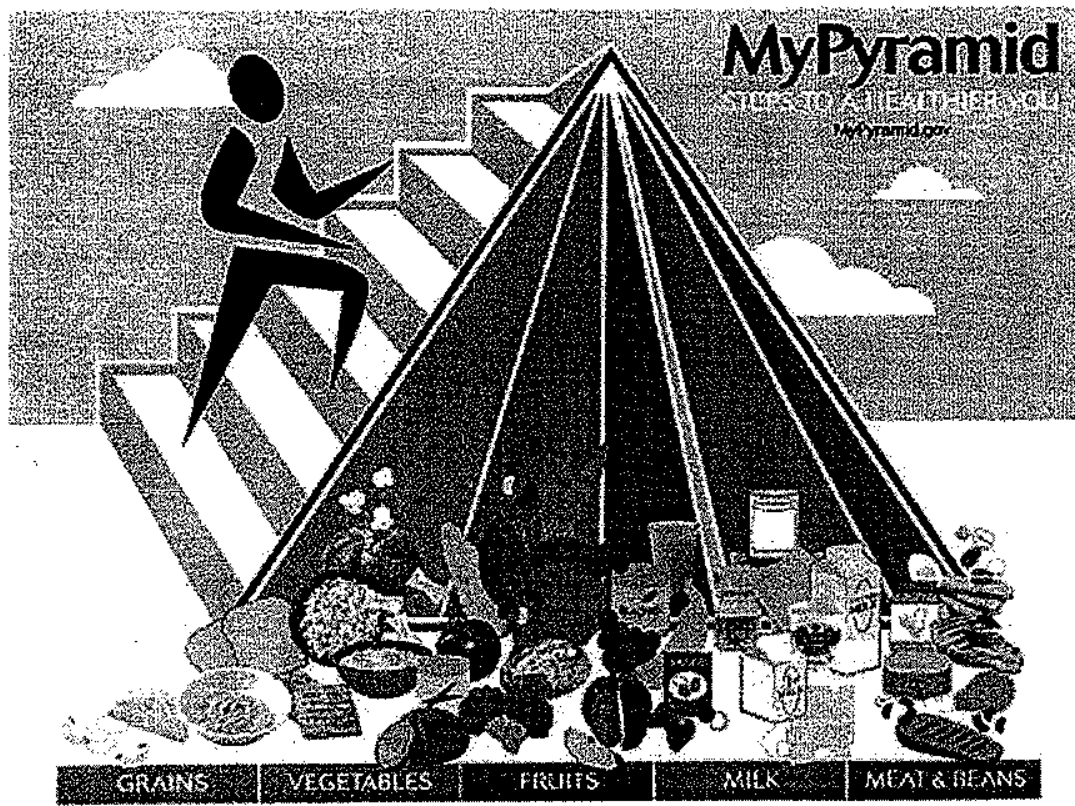

ferent from the existing form. Important distinctions might be made between 'good' and 'bad' carbohydrates, 'good' and 'bad' fats - for example, whole wheat bread is pretty good, white bread very bad; olive oil is good, Crisco very bad (Buckley 2004: 4). As it turned out, the revision released in April 2005 - and labelled as 'MyPyramid' - was widely viewed as an incoherent compromise, the USDA avoiding the responsibility of giving blanket dietary advice to the population as a whole and certainly not counselling eating 'less' of anything (figure 9.2). 'One pyramid does not fit all of us,' said the Agriculture Secretary Mike Johanns, 'so we created 12 different ones' (Burros 2005: A21). ${ }^{5}$

Among academic experts, Dr Walter C. Willett, of the Department of Nutrition at the Harvard School of Public Health, was leading the charge: "The [old] Food Pyramid is tremendously flawed. It says all fats are bad; all complex carbohydrates are good; all protein sources offer the same nutrition; and dairy should be eaten in high amounts. None of this is accurate' (Willett 2001b). The probable causes of this knowing
Figure 9.3 Willett's Proposed Food Pyramid

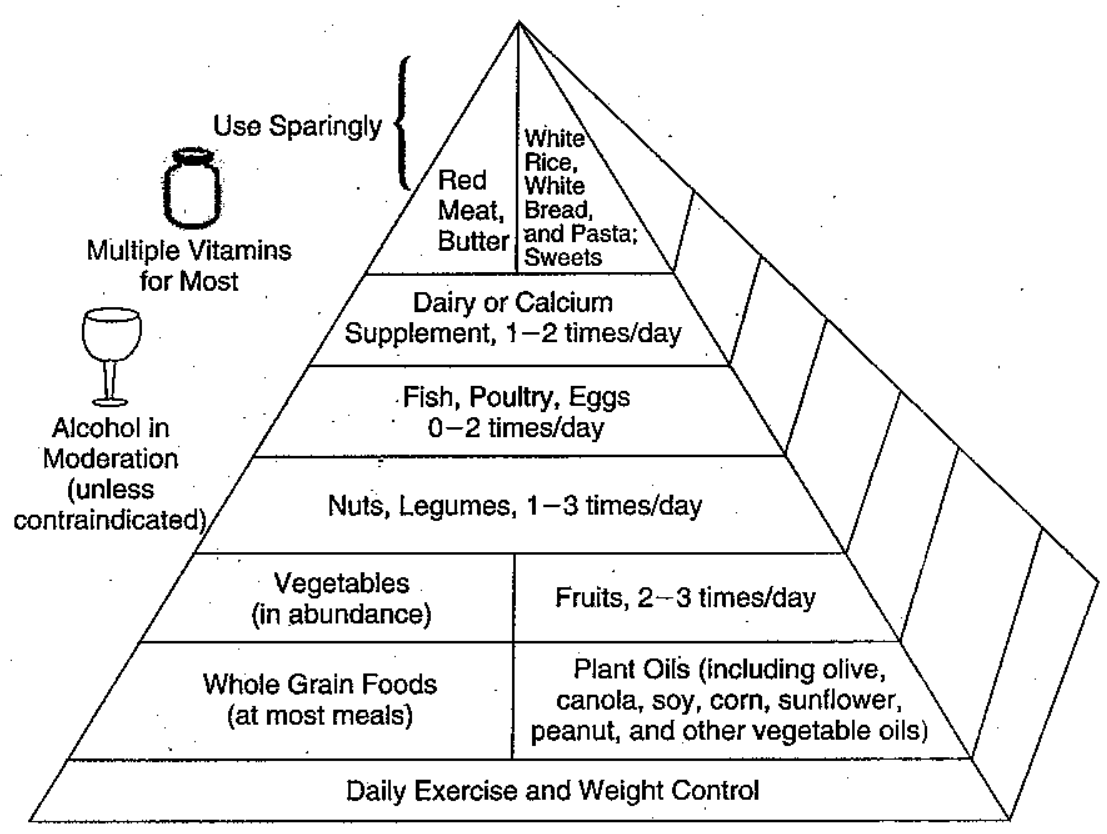

(c) Reproduced from Eat, Drink, and Be Healthy by Dr. Walter C. Willett (New York: Simon and Shuster 2001).

dissemination of bad advice were, first, that 'many nutritionists decided it would be too difficult to educate the public about [the] subtleties' involved in discriminating among carbohydrates and fats and, second, that the USDA Pyramid was a nutritional icon substantially shaped by the political and economic interests of the food industry. Nor was there any convincing evidence that individuals adhering most rigorously to the counsel of the USDA Pyramid had improved health outcomes attributable to their diet: true, they did have 'a lower risk of major chronic disease,' but, Willett found, these same individuals also smoked less and, in general, led 'healthier lifestyles' (Willett and Stampfer 2003: 20). Instead, Willett proposed à conceptually jumbled 'Healthy Eating Pyramid' (figure 9.3) with 'exercise and weight control' at the base, complex carbohydrates and mono- or polyunsaturated vegetable oils just above, and moderate alcohol and multi-vitamins hanging in space off to the side (24). 
Figure 9.4 The Atkins Food Pyramid

\section{ATKINS LIFESTYLE FOOD GUIDE PYRAMID"}

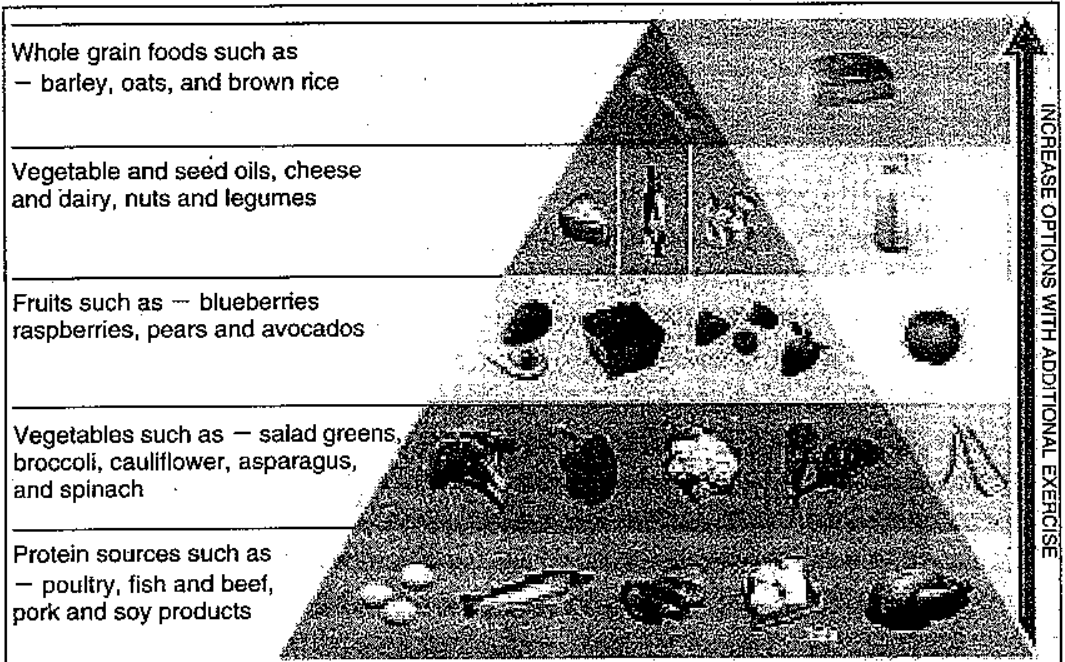

And then there are the experts who actually sell books -lots of books - the ones who are clearly winning in the marketplace of dietary credibility. And here the crucial names were Atkins and Agatston - both of whom turned the USDA Pyramid upside down and commended lots of protein and fat and tight control of the carbs (Atkins 1972, 1992, 2003; Agatston 2003) (figure 9.4). Since Dr Robert C. Atkins's Diet Revolution first appeared in 1972, over 16 million copies of its various versions have been sold worldwide; 30 million Americans have said they have given it a go; and it was almost as successfully globalized as McDonald's, that paradigm of American globalization (Bentley 2004). ${ }^{6}$ Atkins was very big in Britain, in Scandinavia, and, amazingly, in Italy, where there was a certain amount of panic among the pasta makers. In its U.S. heartland, few academic experts were won over, but their lives were being made more and more uncomfortable as their constituencies increasingly voted with their gut instincts. The New York Times Magazine pronounced Atkins vindicated, declaring that USDA Pyramid-type academic expertise may all along have been 'a Big Fat Lie' (Taubes 2002).
And so the question is put: what are the grounds of dietetic credibility? Why did Atkins, and many others of the low-carb popular writers, do so well in the public credibility market, while academic expertise is struggling to make its voices heard? That is a complex question, and all I want to do is to suggest some features of the credibility economy that figure here and that have got some interesting connections with how we tend to think about science and common sense (or lay knowledge) more generally. There are all sorts of considerations I am going to set aside for these purposes, and which are doubtless very important: for example, the fact that Americans like to eat meat and that it is relatively cheap; the possible route that low-carb regimes offer for the masculinization of dieting; a dialectical oscillation in diet fads - low-carb, highprotein fashions alternating with the high-carb, low-protein orthodoxies of the recent past; a rhetoric of luxury, metabolic causation of obesity, and the disavowal of will power that resonates beautifully with current American fashion and academic theory. ${ }^{8}$

First, there is the matter of who is an expert and, therefore, entitled to public authority. That is not a simple question either. Presumably, attending to any given writer implies the recognition of expertise: who would put their health in the hands of someone who they reckoned did not know what they were talking about or who did not possess special and superior knowledge? What is, however, crystal clear is that membership in an academic institution, or in a credentialed expert community, is not, in this specific case, much of a public warrant of expertise and may even count as a liability. One of the most pervasive tropes one finds in the popular dietetic literature is a studied disavowal of credentialed expertise. So while Atkins was a physician, he quickly assured his vast readership that he was a cardiologist and not a diet doctor, drawn ineluctably to his calling by simple, but vast, experience of what actually worked and did not work: 'Looking back at this period in my life I realize what a fortunate thing it was that my training has been in cardiology and not in metabolism. If I had been trained in nutrition and metabolism, I'd be parroting the same classical misconceptions that so many of my colleagues still hang on to. Being free of these misconceptions, allowed my mind then - and since - to approach the observable facts without prejudice' (Atkins 1972: 22).

Dr Agatston of the South Beach Diet does just the same, insisting that his institutionally acquired expertise was even more distant from dietetics. He was a physician specializing in CT imaging technology. Right up front, Agatston boasts that 'I'm not a diet doctor.' Discontented with 
the obvious inefficacy of the American Heart Association-approved low-fat regimen, he was forced to face facts and to develop a diet that actually worked (Agatston 2003: 6-7). So too, Dr Tarnower of the late 1970s Scarsdale Diet: 'Nobody could be more delighted and surprised at the extraordinary success of the Diet than I, since I am not a "diet doctor"' (Tarnower and Baker 1979: 2). Not being a doctor at all can even be a recommendation: Judy Mazel (1981) of the early 1980s Beverly Hills Diet so stated, getting her physician friends to testify to their amazement and delight at her success. A book by two registered dietitians details their initial struggle to arrive at a radical weight-control Truth that nevertheless stood starkly opposed to their profession's key tenets: 'How could we, as nutritionists (registered dieticians), trained to look at the connections between nutrition and health, sanction a way of eating that seemed to reject the very foundation of our [profession's] knowledge and philosophy?' (Tribole and Resch 1995: xv). Of course, there is a lot of metabolic science in Atkins's books - though not so much in Agatston and many others: all the stuff about ketosis, hyperinsulinism; and glycemic indices that is well on its way to being vernacularized in American lay talk about the human body and its aliment. But, although Atkins reckoned it was important that you be told the science of why his diet works, his protestation that he is not a 'diet doctor' gives adequate indication that this is not his personal expertise, so there is no more reason to believe him on the theory of ketosis than many of his expert opponents. Expertise can be an ambiguous category in dietetics: what count as the insignia of expertise in one register may be identified in another as disqualifications.

The grounds on which credentialed expertise is so vigorously disavowed bear inspection: the popular writers identify that kind of expertise as interested, invested in the theories of orthodoxy, and, accordingly, biased, while they want themselves seen as free-booting, anti-establishment independents. They speak a Truth inconvenient to the Vested Interests and cut free of those expert theoretical investments that afflict the academy and the medical profession. That is a sentiment well worth considering for those who think that the academy and the professions still represent the voice of integrity in the wider culture. But in this case studied rejection of credentialed expertise points to something else going on. It testifies to substantial differences in how expert knowledge is represented and brought to bear on questions about 'what should be done.'

Ore telling contrast between the writings of not just Atkins and the academic nutritional establishment, but between virtually all the bestselling writers and the establishment, concerns the question of a science of the particular versus a science of the universal. ${ }^{9}$ Look up dictionary definitions of 'science,' and you will see an overwhelming disposition to define science as the search for, and accumulation of, knowledge of universal scope. ${ }^{10}$.That is why Simplicio lost the argument with Salviati in Galileo's Dialogue: when Simplicio noted that Galilean idealizations worked well in the abstract but rarely if ever fit concrete instances, Salviati recognized a peasant when he heard one. Salviati/Galileo (1967) wanted to know how bodies moved through ideal, frictionless media; Simplicio wanted to know how a particular body moved: 'These mathematical subtleties do very well in the abstract, but they do not work out when applied to sensible and physical matters' (203). In fact, there are many present-day sciences of the particular, though you would not know it from the definitions: all those people trying to work out when the next Cascade volcano will go off, or when the next earthquake in San Francisco will occur, are practising sciences of the particular. I would guess - though I can provide no firm statistics to support the guess - that the majority of people categorized in census data as 'scientists' work within sciences of the particular. Many expert practices can be viewed as hybrid: civil engineering, it is said, 'depends upon' physics but every bridge is different; medicine 'depends upon' physiology in the same way, but every sick body is different. And you cannot 'idealize' away either the unique geology of San Francisco or the unique physiological state of Professor Shapin's liver.

You can eliminate Simplicio's voice from the body of expertise, but there is a price to be paid. That price may not be consequential public disapproval - the American public have almost always been willing to pay the substantial bill for theoretical physics, and, for all the talk of 'public hostility to science,' scientists continue to be held in exceptionally high esteem and science research budgets continue to go up - but it is likely to be public 'unconcern.' This is not a big problem for physics, but it is a very big problem for those expert practices that purport to engage with the question 'What should de done?' Dietetics is certainly one of these practices. It would be quite wrong to say that academic nutritional experts are trying to shrug off the responsibility of giving practical advice. But they go about it in a significantly different way than Dr Atkins.

First, consider the philosophically crucial divide between the objective and the subjective. As a global generalization, I do not think that 
more than a tiny fraction of academic scientific writing on practical dietetics ever addresses what food and eating mean. Eating is treated as an instrumental act: here is what you want to do to avoid diabetes, heart attacks, colon cancer, Alzheimer's, death. The assumption is that the recipients of advice are like the subjects in rational decision theory, maximizing their utilities, and expert advice just tells people - to the best of the expert's ability - how to achieve this maximization most effectively. This is how Harvard's Walter Willett (2001a) starts his exercise in extending academic nutritional expertise to a wider audience: 'We eat to live. It is a simple, obvious truth. We need food for the basics of everyday life - to pump blood, move muscles, think thoughts. But we can also eat to live well and live longer. By making the right choices, you will help yourself avoid some of the things we think of as the inevitable penalties of getting older' (15). As he says later in the book, with a self-conscious gesture at a Wall Street Weltanschauung, 'that is not a bad return on investment' (180). ${ }^{11} \mathrm{I}$ do not doubt that people want to live as long and as healthily as possible, but this is not the only thing that people do when they eat. They eat because they feel bad, or because they feel good. They eat to celebrate or to mourn, to establish claims to status, to affirm or deny group identity. They eat to be sociable, and sometimes they eat like other people eat in order to be sociable. You would not know any of this if you read the works of almost all academic scientific experts on nutrition. (Actually, I tell a slight lie: these writers do have a view on why people eat irrationally, and that is because the rational voice has been made inaudible in the culture by advertising and marketing. So people are still taken as rational maximizers, but they have been given the wrong information on which to do their rational calculations.) In the best-selling literature, however, you cannot miss engagement with the emotional and social meanings of eating. It should come as no surprise; then, that the laity might recognize in this literature a sense of pertinent aboutness that they may not see in academic writing.

Second, academic dietetic expertise treats human bodies in general and as populations. If you weigh this amount, or if you drink this amount, your chances of contracting or avoiding this or that dread disease is $n$ per cent, or your risk of it is elevated or decreased $n$ per cent. This can be useful information, most especially for policymakers, and let us grant for the moment that it is reliable, even though the domain of such academic statements remains notoriously conflicted. The problem, however, is that individual people tend to be interested in what is likely to happen to them. The answer for any specific individual will either be colon cancer or no colon cancer, die before age 75 or after age 75. What any individual wants to know is what it is going to be like for them, an answer to what one historian of medicine has called 'the patient's fundamental question - why me?' (Marks 1997: 171). As the cognitive psychologist Gerd Gigerenzer (2003) has brilliantly pointed out, we are organisms that seem to have evolved to take in natural frequencies (say, three out of ten people) rather than probabilities (say, 30 per cent), and there is a consequent problem of misunderstanding risk between experts and laity. But the issue to which I draw attention is that people - the recipients of expert counsel - are interested in themselves as unique particulars, not as members of populations, and I see no way to say they are wrong to do so. They are particulars, and it is plausible to think that they approach statements about populations as statements about particulars. Expertise about populations just cannot give that answer to any individual, whether expressed in natural frequencies or probabilities, but it does not follow that individuals may not want it anyway and look for expert writing that gives signs that it considers such a desire legitimate and intelligible. The difference should not be thought of as one between knowledge and ignorance, between cognitive virtue and cognitive error, but one between different kinds of concerns. You cannot use better logic or more evidence to refute a different kind of concern.

The popular literature acknowledges this circumstance. The style is overwhelmingly casuistical. That is, while there may be much metabolic science of general scope in any given text, the books are quite generally structured around particular cases. ${ }^{12}$ Indeed, they often are organized as a kind of counterpoint between the general and the populational, on the one hand, and stories about, say, Mrs Finkeistein; a forty-nine-yearold woman weighing 212 pounds, on the other. Case follows case, testimonial follows testimonial. Dr Atkins barely gets his story underway before we are introduced to Stanley Moskowitz, 'a vigorous 64-year-old sculptor who had survived three heart attacks,' who was overweight, who was addicted to junk food, and who, under Atkins's tutelage, learned the delights of low-carb dieting. Then Mary Anne Evans gets to 'tell her own story,' a forty-two-year-old, 209-pound woman who had abandoned all hope before she achieved low-carb redemption (Atkins 1992: 10-14). The somewhat less folksy and rhetorically more restrained Dr Agatston (2003) interleaves expert nutritional reasoning with typographically distinct stories about individual cases: Karen $G$. shares with 
us the effects of divorce on eating patterns (14-16); Ellen P. explains that she decided to lose weight because her 'oldest daughter's bat mitzvah was coming up' (23-4); Daniel S. confesses to back-sliding pasta consumption and serves as an illustration that South Beach does not presuppose absolute purity of commitment (30-1).

You could describe this casuistical style as a deliberate attempt at credibility engineering, and that would almost certainly be correct, but it is also possible to interpret it as a response to the concerns which deliver the reader to the text. That is the sort of thing they expect to hear. True, Mrs Finkelstein is not you, but she is, and is here presented as, a unique individual, not a population, and the metaphorical extension from aspects of her predicament to yours is available for you to make if you happen to feel her case to be sufficiently like your own. That is one way in which the popular writings are in a direct lineage of early modern medical traditions, which were focused on the idiosyncrasies of individual sick bodies whose workings the physician attempted intimately to understand (Jewson 1974). Enjoying special authority, both in early modern medicine and in the contemporary best-selling dietetic literature is 'the case of the author' - a confession of how the author stood before undertaking the proposed dietary discipline and how it turned out for him or her - invariably, of course, very well indeed. In the mideighteenth century, the most celebrated diet doctor in England, the enormously fat Dr George Cheyne, devoted thirty pages of his celebrated The English Malady to 'The Case of the Author,' and in 1972 the most famous diet doctor of his day, Dr Robert Atkins, told his readers how, as a medical student, he 'had the reputation of being the biggest chow-hound in the hospital' (Shapin 2003b; Guerrini 2000). So deep was he in denial of his own condition that it was not until he was in his thirties that he realized he had 'three chins.' If you find dieting hard, Dr Atkins (1972: 21) assures you that so too did he: he understands your difficulties. So far as I can now see - though future reading may prove me wrong - there are no cases in the academic literature. ${ }^{13}$

An early modern maxim - used as much by analogy outside of medicine as within it - was 'Physician, cure thyself.' You might well want to take the expert advice of healthy and slim physicians, just because they gave embodied warrants of sincerity as well as efficacy, and one thing you might well want to know about those attempting to give you expert advice is whether they took it themselves, and to what effect. ${ }^{14}$ That is what an interviewer asked Walter Willett, and, having told readers next to nothing about his own regimen in his expert writings, Wil- lett responded to his interviewer directly: Interviewer: 'What do you typically eat in any given day?' Willett: 'For breakfast, I'll usually have something like cooked whole grains with fruit. Lunch may be leftover grains from breakfast as part of a salad, with vegetables, and nuts. Dinner is usually salad or vegetables with tofu, chicken or fish.' Interviewer: 'What about secret indulgences?' Willett: 'Sometimes I'll have some flavorful cheese or a bit of chocolate' (Willett 2001b). ${ }^{15}$ Having offered his own case to launch his 1972 text, when Atkins died in 2003, much attention focused on the circumstances of his death. From within the academic scientific point of view, it is hard to see why that should matter: probabilities being what they are; why shouldn't you 'do as I say, not as I do,' and why shouldn't someone following his own excellent advice nevertheless suffer a heart attack at age 71 and wind up dead on a Manhattan pavement at age 72? Assuming that Atkins followed his own diet, and assuming that he reduced his chance of a heart attack by, say, 50 per cent, the fact that he nevertheless suffered a heart attack should not affect the credibility of his diet: that's probabilities for you. But in this case it was rather harder to gloss away a New York death certificate which shows that at the time of his death Dr Robert Atkins weighed $258 \mathrm{lbs}$ and was, according to his own criteria, and those of the Centers for Disease Control, 'clinically obese' (McLaughlin 2004 and Kleinfield 2004). So consider the contrast between regimes of credibility in which such a circumstance makes no difference and one in which it makes all the difference. Out of such a consideration, I suggest, might come an interesting new way of parsing the sciences and of describing the different conditions of their credibility. Less ambitiously, I have offered a sketch of some reasons - other than the simple distribution of unpalatable truth and appealing falsity - why the popular writers are popular and why the academic experts are not.

\section{NOTES}

1 For contrasts in the conditions of credibility confronted by different kinds of expert practices, see Shapin (1995).

2 A fine study of divided and politicized nutritional expertise and expert advice to the American government during the 1980s is Hilgartner (2000).

3 According to Dr Keith-Thomas Ayoob (of the Albert Einstein College of Medicine), testifying on behalf of the American Dietetic Association in the USDA's Great Nutrition Debate of February 2000, 'a recent Gallup poll 
found that 86 percent of dieters like the USDA food guide pyramid. They thought it was a common, no nonsense approach to managing weight in the long term, even though 40 percent of those people had at some point tried a high protein/low carbohydrate diet.' http://www.usda.gov/cnpp/ Seminars/GND/Proceedings.txt (accessed 24 August 2004).

4 For a transcript of the Great Nutrition Debate, see http://www. cnpp/Seminars/GND/Proceedings.txt (accessed 24///www.usda.gov/

5 Critics

tained in the 2005 Detary Gumid did not accurately represent advice contained in the 2005 Dietary Guidelines for Americans, published in January 2005; and soon MyPyramid was becoming an object of satire and political criticism - some opponents referring to it as 'McPyramid' because of its alleged compromises with the food industry. See, e.g., Severson (2005).

6 As of August 2005, Arthur Agatston's South Beach diet books have sold 10 million copies world-wide (Warner 2005a).

7 Amy Bentley (2004: 37) notes that Atkins's book 'maintained a modicum of popularity' through the 1970s and 1980s - a bit of an understatement - but caught a swiftly rising American tide of low-carb sentiment in the late 1990s and enjoyed an enormous surge of popularity, probably peaking in the sum mer of 2002, when Taubes's New York Times Magazine article was published. As late as September 2004, carb-dependent companies were facing enormous financial pressures from the low-carb craze: Interstate Bakeries (the makers of Wonder Bread and Twinkies) filed for Chapter 11 bankruptcy, citing pressure from the Atkins Diet. But from the middle of 2004, journalistic pieces began to appear announcing that the low-carb phenomenon had either passed its peak or had reached a plateau (e.g., Warner 2004). A yearend review announced that 'it was probably inevitable that the year that started with a boom in low-carb diets would end in a bust in low-carb diets' (Zernicke 2004). The piece described mounting inventories of unsold lowcarb foods in manufacturers' warehouses and speculatively attributed the demise of the Atkins diet to a combination of health warnings, ineffectiveness, resulting bad breath, and the fact that it was just too boring. By spring 2005 , there was solid evidence that the low-carb fad had passed its peak, and newspaper pieces appeared with such headlines as 'Ding Dong, the Craze Is Dead' (Yonan 2005). That article claimed that the number of Americans on a low-carb diet had declined from a February 2004 peak of 9.1 per cent to 2.4 per cent in December 2004, before recovering to 4.4 per cent in March 2005. And on 31 July 2005 Atkins Nutritionals, Inc. itself filed for Chapter 11 bankruptcy protection, a last-ditch effort to save the company, but a clear sign that the end was nigh. Accordingly, a British television news agency announced that the Atkins 'craze' was 'officially' over ('The Atkins
Diet Crashes' 2005). The company at the same time announced its intention to refocus on nutrition bars and drinks, becoming a smaller firm not specifically orientated towards weight loss but catering 'more broadly for consumers who are concerned about health and wellness' (Warner 2005b: A12; LeSure 2005: A5). At the time, a food industry consulting firm concluded, 'Now there is almost no market for low-carb food products' (Bob Goldin, of Technomic Inc., quoted in Hirsch 2005: A1). Early in 2006, the company emerged from bankruptcy with a new management team - much of which came from the French food and bottled-water group Danone - aiming to compete in the highly competitive nutrition bar and shakes market (Grant 2006: 13).

8 The best source for the history of dietary fashion is Schwartz (1986). Modern low-carb fashion is related to changing sensibilities about personal responsibility in Shapin (2004). Bentley (2004) offers a concise summary of the current state-of-the-low-carb art, while making the valuable suggestion that 'Atkins allows men to feel comfortable admitting in public that they are dieting' and observing that 'companies such as Atkins Nutritionals ... appear to be courting the male dieter with resolve' (35).

9 I gesture here at Socrates' rejection of the very idea of a science of the particular, as, for example, in the Phaedrus (249c): 'For a man must have intelligence of universals, and be able to proceed from the many particulars of sense to one conception of reason; - this is the recollection of those things which our soul once saw while following God - when regardless of that which we now call being she raised her head up towards the true being. And therefore the mind of the philosopher alone has wings.' Jacques Lacan referred to psychoanalysis as 'the science of the particular' (Lacan 1954).

10 Webster's 3rd Unabridged, definition 3a: 'accumulated and accepted knowledge that has been systematized and formulated with reference to the discovery of general truths or the operation of general laws.' Webster's 10th Unabridged, definition 3a: 'knowledge or a system of knowledge covering general truths or the operation of general laws.' Oxford. English Dictionary, definition 4a: 'A branch of study which is concerned either with a connected body of demonstrated truths or with observed facts systematically classified and more or less colligated by being brought under general laws.'

11 I focus attention on Dr Willett's work because he is a well-known nutritional expert, writing from the centre of academic authority, who has been dedicated to addressing a wider public and who has attempted to meet that public on what he takes to be its own terms. This is a well-written, wellorganized, and passionate book, and if I seem to criticize some of its assumptions and expository conventions, it is because it is one of the best 
representatives of a genre of academic expert writing. Needless to say, I pretend to no technical expertise in dietetics and can have no opinion on scientific claims and practical outcomes.

12 For the history of casuistry in moral reasoning, see Jonsen and Toulmin (1988).

13 I except the clinical journal literature, where discussions of clinical cases are the norm.

14 A study of René Descartes's medical counsel from this point of view is Shapin (2000); see also Shapin (2003b). Of course, there are reasons you might wish to take the advice of obese physicians - because they might be thought to understand your predicament - and this was indeed the case with many of Cheyne's patients.

15. Willett (2001a: 11-13) tells readers briefly about the author's Michigan dairy farming family, his membership in the 4-H club, and his victory in a National Junior Vegetable Growers Association competition, but I marked only two brief mentions of his own dietary habits - first, an assurance that he and his Harvard colleagues have 'substantially modified our activity levels and $\operatorname{diet}^{\prime}$ (13) as a result of their expert findings, and, later, in the recipe section, some remarks about his 'Busy Day Menu': some left-over Kashi with bits and pieces added: 'I put all this in my backpack, dash out the door with my bike, and I'm in my office at the Harvard Medical area in fifteen minutes ... In the evening, if I'm lucky, my wife, Gail, may have made one of the entreés from this book, or one of countless other healthy creations, for dinner' (213-14).

\section{REFERENCES}

Agatston, A. 2003. The South Beach Diet: The Delicious, Doctor-Designed, Foolproof Plan for Fast and Healthy Weight Loss. New York: Random House. Atkins, R.C. 1972. Dr Atkins' Diet Revolution: The High Calorie Way to Stay Thin
Forever. New York: David McKay.

- 1992. Dr Atkins' New Diet Revolution. New York: Avon Books.

- 2003. Atkins for Life: The Complete Controlled Carb Program for Permanent Weight Loss and Good Health. New York: St Martin's Press.

The Atkins Diet.Crashes. 2005. ITV.com, 1 August. http://www.itv.com/news/ world_1987245.html (accessed 5 September 2005).

Barnes, B. 1982. About Science. Oxford: Basil Blackwell.

Bentley, A. 2004. The Other Atkins Revolution: Atkins and the Shifting Culture of Dieting. Gastronomica: The Journal of Food and Culture 4, no. 3: 34-45.
Buckley, N. 2004. Battle Rages over How to Build the New Food Pyramid. Financial Times, 19 August.

Burros, M. 2005. U.S. Introduces a Revised Food Pyramid. The New York Times, 20 April.

Collins H., and T. Pinch. 1998a [1993]. The Golem: What You Should Know about Science, 2nd ed. Cambridge: Cambridge University Press.

Collins, $\mathrm{H}_{\text {., }}$ and T. Pinch. 1998b. The Golem at Large: What You Should Know about Technology. Cambridge: Cambridge University Press, 1998.

Galileo Galilei. 1967 [1632]. Dialogue Concerning Two Chief World Systems, 2nd ed. Translated by Stillman Drake. Berkeley: University of California Press.

Gigerenzer, G. 2003. Calculated Risks: How to Know When Numbers Deceive You. New York: Simon and Sehuster. Published in the United Kingdom as Reckoning with Risk: Learning to Live with Uncertainty. London: Penguin.

Grant, Jeremy. 2006. Atkins' Quest to Put the Lean Years Behind It. Financial Times, 13 April.

Guerrini, A. 2000. Obesity and Depression in the Enlightenment: The Life and Times of George Cheyne. Norman: University of Oklahoma Press.

Helmich, N. 2002. Scales Tip in Favor of a New Food Pyramid. USA Today, 4 November. http://www.usatoday.com/news/health/2002-11-04-foodpyramid_x.htm (accessed 28 September 2004).

Hilgartner, S. 2000. Science on Stage: Expert Advice as Public Drama. Stanford, CA: Stanford University Press.

Hirsch, Jerry. 2005. The Nation: Carb Supporters Rejoice as Atkins Goes Belly Up. Los Angeles Times, 2 August.

Jewson, N.D. 1974. Medical Knowledge and the Patronage System in Eighteenth-Century England. Sociology 8: 369-85.

Jonsen, Albert R., and Stephen Toulmin. 1988. The Abuse of Casuistry: A History of Moral Reasoning. Berkeley: University of Califorria Press.

Keys, A., and M. Keys. 1959. Eat. Well and Stay Well. Garden City, NY: Doubleday.

Kleinfield, N.R. 2004. Just What Killed the Diet Doctor, and What Keeps the Issue Alive? The New York Times, 11 February.

. Lacan, Jacques. 1954. Le Séminaire de Jacques Lacan. Seminar I, 20 January. http://perso.numericable.fr/ desylvie/sem01/03Sem1.htm (accessed 12. October 2004).

LeSure, Elizabeth. 2005. Low-Carb Company Atkins Files for Bankruptcy. Boston Globe, 1 Áugust.

Marks, H.M. 1997. The Progress of Experiment: Science and Therapeutic Reform in the United States, 1900-1990. Cambridge: Cambridge University l'ress. 
Martin, P. 2003. Shaping Our Diet. Spiked, 28 October. http://www.spikedonline.com/Printable/00000006DF9C.htm (accessed 28 September 2004) Mazel, J. 1981. The Beverly Hills Diet. New York: Macmillan.

McLaughlin, K. 2004. Report Details Dr Atkins' Health Problems. Wall Street Journal, 10 February.

Montaigne, M.E. de. 1965 [1580, 1588]. Of Experience. In The Complete Essays of Montaigne, translated by Donald M. Frame, 815-57. Stanford, CA: Stanford University Press.

Nestle, M. 2002. Food Politics: How the Food Industry Influences Nutrition and Health. Berkeley: University of California Press.

Rees, M. 2005. Think Big, Like Einstein. Connected.Telegraph, 26 January. http:// www.telegraph.co.uk/connected/main.jhtml?xml=/connected/2005/01/ 26/ecrein26.xml\&sSheet=/connected/2005/01/26/ixconnrite.html (accessed 23 April 2007).

Schwartz, Hillel. 1986. Never Satisfied: A Cultural History of Diets, Fantasies and Fat. New York: Doubleday Anchor. Severson, Kim. 2005. The Government's Pyramid Scheme. The New York Times,
24 April.

Shapin, S. 1992. Why the Public Ought to Understand Science-in-the Making. Public Understanding of Science 1 (1992): 27-30. - 1995. Cordelia's Love: Credibility and the Social Studies of Science. Perspec-
tives on Science 3: 255-75.

- 2000. Descartes the Doctor: Rationalism and Its Therapies. The British Journal for the History of Science 33: 131-54

- 2002. Barbecue of the Vanities. London Review of Books, 22 August. http:// books.guardian.co.uk/lrb/articles/0,6109,777310,00.html (accessed 23 April 2007).

- 2003a. How to Eat Like a Gentleman: Dietetics and Ethics in Early Modern England. In Right Living: An Anglo-American Tradition of Self-Help Medicine and Hygiene, edited by Charles E. Rosenberg, 21-58. Baltimore, MD: Johris Hop-
kins University Press.

- 2003b. Trusting George Cheyne: Scientific Expertise, Common Sense, and Moral Authority in Early Eighteenth-Century Dietetic Medicine. Bulletin of
the History of Medicine 77: 263-97.

- 2004. The Great Neurotic Art. London Review of Books, 4 August, 14-16. http://www.Irb.co.uk/v26/n15/shap01_.html (accessed 23 April 2007).

Tarnower, H., and S.S. Baker. 1979. The Complete Scarsdale Medical Diet, Plus Dr Tarnower's Lifetime Keep-Slim Program. New York: Bantam.

Taubes, G. 2002. What If It's All Been a Big, Fat Lie? New York Times Magazine, 7 July. http://query.nytimes.com/gst/fullpage.html?sec=health\&res= 9F04E2D61F3EF934A35754C0A9649C8B63 (accessed 23 April 2007).
Tribole, E., and E. Resch. 1995. Intuitive Eating: A Revolutionary Program That Works. New York: St Martin's Press.

Tolstoy, L. 1937 [1899]. Modern Science. In Recollections and Essays, translated by Aylmer Maude, 176-87. London: Oxford University Press.

Warner, Melanie. 2004. Is the Low-Carb Boom Over? The New York Times, 5 December.

- 2005a. Atkins Diet Saga Now at Chapter 11. The New York Times, 3 August. - 2005b. Atkins Files Bankruptcy Petition. The New York Times, 1 A ugust.

Weber, M. 1991 [1918]. Science as a Vocation. In From Max Weber: Essays in Sociology, edited by H.H. Gerth and C. Wright Mills, 129-56. London: Routledge. Willett, W.C. 2001a. Eat, Drink, and Be Healthy: The Harvard Medical School Guide to Healthy Eating. New York: Free Press.

- 2001b. Nutrition Book Author Willett Rebuilds USDA Food Pyramid. Harvard Public Health NOW, 24 August. http://www.hsph.harvard.edu/now/ aug24/ (accessed 27 April 2007).

Willett, W.C., and M.J. Stampfer. 2003. Rebuilding the Food Pyramid. Scientific American Exclusive Online Issue (January): 19-24. http://www.sciam.com/ article.cfm?articleID=0007C5B6-7152-1DF6-9733809EC588EEDF (accessed 23 April 2007).

Yonan, Joe. 2005. Ding Dong, the Craze Is Dead. Boston Globe, 30 March. Zernicke, Kate. 2004. Fatkins. Thẻ New York Times, 26 December. 